NBER WORKING PAPER SERIES

IDEAS AND EDUCATION:

LEVEL OR GROWTH EFFECTS?

Steve Dowrick

Working Paper 9709

http://www.nber.org/papers/w9709

\title{
NATIONAL BUREAU OF ECONOMIC RESEARCH
}

1050 Massachusetts Avenue

Cambridge, MA 02138

May 2003

The views expressed herein are those of the authors and not necessarily those of the National Bureau of Economic Research.

(C2003 by Steve Dowrick. All rights reserved. Short sections of text not to exceed two paragraphs, may be quoted without explicit permission provided that full credit including Cnotice, is given to the source. 
Ideas and Education: Level or Growth Effects?

Steve Dowrick

NBER Working Paper No. 9709

May 2003

JEL No. O0, O3, O4

\section{$\underline{\text { ABSTRACT }}$}

This paper examines theory and evidence from recent studies into the contributions to economic growth of expenditure on education and on research and development. Investment in human capital has fundamentally different economic attributes to physical investment - exhibiting complementarity, positive feedback and non-rivalry - implying the potential to enhance economic growth over a long time period.

In the case of education, there are debates over whether changes in educational attainment ultimately affect the long-run growth rate of the economy, or only the long-run level of output. The macroeconomic evidence on level effects is consistent with microeconomic estimates of private rates of return to schooling. It appears, however, that there are also significant long-term growth effects - the more educated is the workforce, the better is it able to implement technological advances.

There is consistent evidence of high social rates of return on research and development in both commercial areas of research and in more fundamental research, implying that R\&D is underresourced. A number of studies have emphasised the importance of international technology spillovers, particularly for smaller economies such as Australia.

Steve Dowrick

Professor of Economics

Faculty of Economics and Commerce

Building 26

Australian National University

ACT 0200, Australia

steve.dowrick@anu.edu.au 
The importance of human capital for economic growth was highlighted in much of the 'new growth theory' that came to prominence in the late 1980s and early 1990s. The neo-classical growth model, formalised three decades earlier, had focused on the accumulation of machinery and equipment and emphasised the feature of diminishing returns- which implied that such investment would not be able to drive long-run growth. The new generation of studies switched attention to the accumulation of human capital and the possibility that returns to investment in education, training and research may not suffer from diminishing returns.

There is an important distinction between embodied and disembodied human capital. Human capital in the form of abilities and skills is embodied inasmuch as it lives and dies with particular people. We invest in human capital not only through formal education and training programmes, but also through experience on the job and through domestic and social interaction. The time and effort devoted to parenting, for example, represents an enormous investment in the human capital of the next generation.

The accumulation of abilities contributes both to psychic rewards and to marketed economic activity. Whilst the value of the former is hard to measure, there are relatively straightforward ways for us to measure the latter. Economists are only just beginning to address seriously the task of evaluating non-market activities such as domestic labour see, for example, Folbre and Nelson (2000) and Apps and Rees (2001). I focus in this paper on market-related returns to human capital because we do not yet have internationally standardised valuations of non-market activities.

The most extensively documented feature of embodied human capital is the relationship between education and wages. Studies of earnings in advanced capitalist economies typically find that each extra year of schooling raises earnings by five to ten percent. These findings are confirmed by Australian studies such as Miller et al. (1995), who analyse earnings of twins and find that the return to a year of education lies between $4.5 \%$ and $8.3 \%$, and Preston (1997) who reports high rates of return to advanced educational qualifications. The results of Miller et al. are particularly interesting because they control for the influences of genetic and domestic background to identify the direct contribution of education - following studies by Ashenfelter and Krueger (1994), Ashenfelter and Rouse (1997) and Ashenfelter and Rouse (1998) which estimate US rates of return between nine and sixteen percent.

This evidence leads us to expect that, if the average educational attainment of the working-age Australian population were to rise by one year, real GDP should rise by up to eight percent. This increase in the level of GDP will, typically, take place gradually. An increase in the length of schooling of teenagers will only increase the average educational experience of the adult population as the new, better-educated cohorts enter the workforce, replacing older cohorts. We expect the transition to last four decades, if people enter the labour force aged 20 and exit at an age of about 60 . If this is so, the annual growth rate of GDP will be 0.2 percentage points above trend during the transition period, resulting in an overall $8 \%$ increase, after which time the growth rate will revert to trend - with, perhaps, some lagged adjustment to the stock of physical capital. In this sense, changes in educational investment are predicted to have growth effects in the shortrun (albeit a short-run of forty years), but only level effects in the long-run. 
This is the conventional approach, which treats human capital as an investment good in much the same way as a farmer might consider investing in tractors. There are, however, features of human capital that can give it a much more important role in economic development. This is particularly true when we turn our attention to disembodied human capital, the realm of knowledge and ideas which do not live and die with their inventors but can be transmitted freely between people and carried forward over generations.

A crucial economic attribute of disembodied human capital, highlighted in recent models of endogenous growth, is that ideas are both non-rival and cumulative. Nonrivalry implies that once the idea of using electronic circuits to carry out binary computations has been announced, people can simultaneously use this idea to develop a wide range of applications. One person's use of the idea does not prevent another person from using it at the same time. Moreover ideas are cumulative: the idea of electronic computing has lead to the idea of quantum computing which may in turn lead to yet further ideas.

Analysis of these attributes of non-rivalry and cumulative feedback has led growth theorists to speculate that investment in the generation of ideas can be the engine of long-run growth. The non-rivalry of knowledge also leads us to expect market failure. When others reap the benefits of someone's new ideas, market forces alone are unlikely to generate the optimal level of investment in knowledge - implying a need for government subsidy.

If the generation of disembodied human capital - ideas / technology - is the engine of growth, we should expect to find that embodied human capital - skills and abilities - also affect long-run growth. Ideas do not reproduce themselves without the input of highly skilled researchers. Perhaps of equal importance, the more skilled the workforce, the better they are able to absorb, implement and adapt the new ideas emanating from the R\&D sector. To the extent that technological change is endogenous, we expect educational attainment to have long-run growth effects in addition to the conventional prediction of level effects.

In the following sections I review and evaluate evidence from recent theoretical and econometric studies relating economic growth to investment in both embodied and disembodied human capital. I restrict my attention on the empirical front to the relatively well-documented areas of investment in formal schooling and R\&D, noting that this omits potentially important areas of investment in health and in informal education and training that takes place within the family and within the workplace. 


\section{Re-thinking Economic Growth: the role of knowledge}

Knowledge is fundamental to economic progress. Our material standard of living would be reduced to unrecognisable levels if we were to suffer collective amnesia forgetting that a circular shape reduces friction, not remembering how to read and write, losing all knowledge of electro-dynamics. All economic activities depend on institutions that encourage the preservation, transmission and development of knowledge.

This seems blindingly obvious. Yet for several recent decades, the economic analysis of growth was dominated by an approach that sidelined the role of knowledge. Economists concentrated on the accumulation of objects rather than the accumulation of ideas.

The object-oriented approach to economic growth was formalised in 1956 by two economists operating at opposite ends of the globe: Robert Solow at the MIT in Cambridge and Trevor Swan at the ANU in Canberra. Their neo-classical growth models were formulated independently but in broadly the same way, leading to similar conclusions. Accumulation of capital - machinery, buildings, equipment, etc. - is the engine of growth in the short-run. Policies that increase the share of resources going to investment will raise the productive capacity of the economy. But as the growth of the capital stock outpaces the limited resources of land and labour, the impact of each successive unit of investment is diminished. However large the boost to the investment rate, growth will eventually revert to some fixed rate determined by exogenous technological progress.

This implication of the neo-classical growth model is illustrated in Figure 1. A boost to investment at time $\mathrm{T}_{0}$ raises the rate of growth (the slope of the logarithmic output line) from the solid line A to the dashed line B. Ultimately, however, growth reverts to the exogenous rate, where line B becomes parallel to line A, albeit with output and incomes at a higher level than would have obtained at the lower investment rate. Tax incentives, or other policies that influence investment, affect only the level of output, not the long-run rate of growth.

The key to this conclusion is the assumption of diminishing returns to capital accumulation. Underlying this notion is the idea of capital as a collection of similar objects. A self-employed dress-maker who purchases his first sewing machine will register a large increase in annual output. Purchase of a second machine will reduce the amount of down-time when the first machine is under repair - but the consequent addition to annual output is relatively small. A third machine would probably be redundant. This assumption about diminishing returns is typically captured in growth models by postulating an aggregate production function of Cobb-Douglas form exhibiting constant returns to scale, where output per unit of labour at time $t, y_{t}$, is related to the net capital stock per unit of labour, $\mathrm{k}_{\mathrm{t}}$, as:

$$
y_{t}=A_{t}\left(k_{t}\right)^{\alpha}
$$

The elasticity of output with respect to capital, represented by the parameter $\alpha$, is assumed to be less than unity. The parameter $A_{t}$ represents the level of technology at 
time $\mathrm{t}$, sometimes referred to as total factor productivity.

The marginal product of capital is:

$$
\frac{\partial y_{t}}{\partial k_{t}}=\frac{\alpha A_{t}}{k_{t}^{1-\alpha}}
$$

which, given $\alpha<1$, diminishes towards zero as capital intensity increases.

\section{the revolution in growth theory: endogenous growth}

This way of thinking about economic growth was challenged in a series of papers, starting with Paul Romer in 1986, heralded as 'the new growth theory' or 'endogenous growth theory". A prominent feature of this new wave of economic models, indeed their defining feature, is that policy intervention and the nature of institutions can influence the long-run growth rate of the economy.

\section{Figure 1}

The impact of increased investment in the neo-classical and endogenous growth models

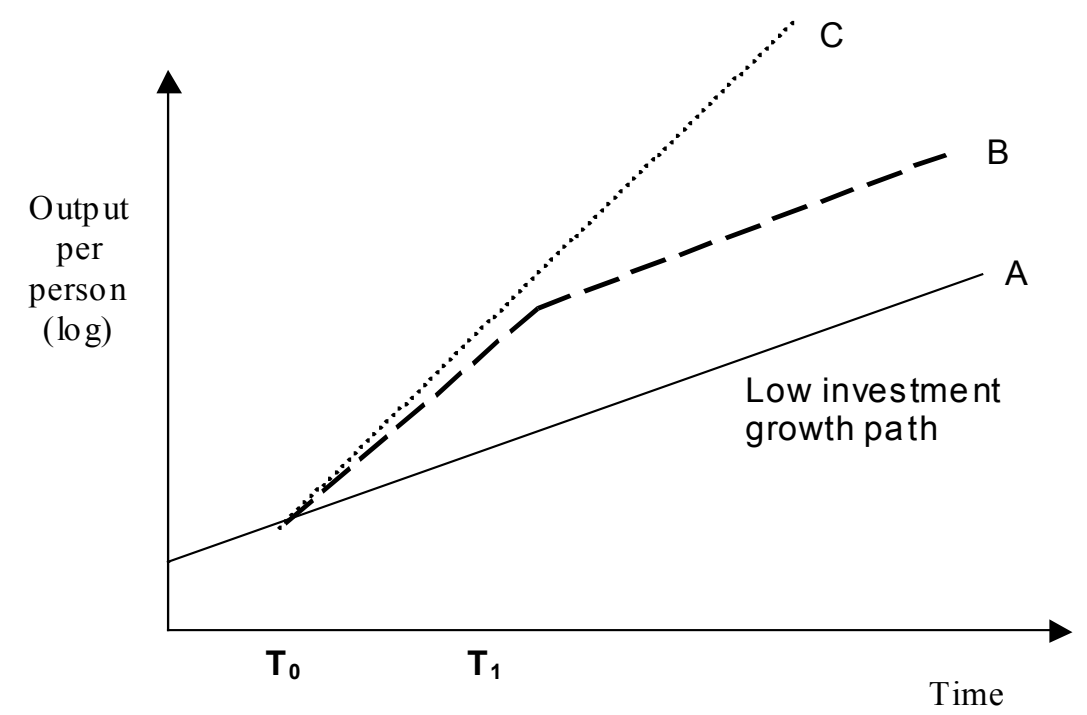

In terms of Figure 1, the new models suggest that policy or institutional change, instituted at time $\mathrm{T}_{0}$, could permanently alter the slope of the growth path - as illustrated by the dotted path $\mathrm{C}$.

There are various technical features of these models that make it feasible for the long-run growth rate to be determined endogenously, i.e. determined by economic

\footnotetext{
${ }^{1}$ The key papers are Romer (1986), Romer (1990), Lucas (1988), Rebelo (1991) and Aghion and Howitt (1992). Romer (1993) acknowledges the intellectual debt due to Adam Smith, Joseph Schumpeter, Arthur Lewis and others. Further important contributions, analysing specialisation, have come from Australian economists: Yang and Borland (1991), Borland and Yang (1992) and Shi and Yang (1995).
} 
behaviour that is analysed within the model. One possibility arises where the degree of substitutability between capital and labour is sufficiently high that returns to the accumulation of capital do not diminish to zero. ${ }^{2}$ We can imagine that this might be the case in some manufacturing processes where human labour is readily replaced by robots, or in the delivery of some financial services such as ATM banking. But it is not clear that this robotic model of growth is applicable to all sectors of the economy.

More interesting, to my mind at least, are models of endogenous growth that build on the economic properties of complementarity, dynamic feedback and non-rivalry in investment. These are the properties that distinguish the accumulation of ideas and skills from the accumulation of objects. It is worthwhile considering each of them in turn.

\section{Complementarity of investment}

Complementarity arises when your investment increases the return (monetary and/or psychic) to my investment. This may occur when we invest in activities that exhibit network externalities. Learning to play chess, to speak Esperanto, or to read and write becomes much more rewarding for me if others invest in the same skills. Complementarity is not exclusive to investment in human capital; the benefits I get from investing in a telephone line and a fax machine are also enhanced when others do the same. But complementarity is probably more pervasive in the accumulation of skills than in the accumulation of objects. Indeed such complementarity is an essential ingredient of the development of 'social capital'.

Complementarity is a feature of the endogenous growth model of Lucas (1988) where the productivity of any worker is enhanced not only by their individual level of skill but also by the average skill level amongst their fellow workers. This implies that the economic analysis of external effects is relevant to growth. Although my productivity depends in part on your human capital, I cannot expect you to take that into account when you decide how much education and training to undertake - and vice versa. So if we make individual decisions about the time and money we spend on education and training, we are likely to under-invest. It follows, from Lucas's analysis of such externalities, that there may be an important role for government to play. Subsidising education will improve economic welfare in the sense that everyone will be better off as a result of an increase in human capital. ${ }^{3}$

\section{Dynamic feedback}

These education externalities are not, however, sufficient in themselves to drive long-run growth. In Lucas' model, the rate of output growth is still limited by diminishing returns to the accumulation of both physical and human capital. He endogenises growth by appealing to another feature of education: dynamic feedback. As we learn more, it becomes easier to acquire further knowledge and skills. An obvious

\footnotetext{
${ }^{2}$ This possibility was canvassed by the Australian economist, John Pitchford (1960), who illustrated his argument using a Constant Elasticity of Substitution production function.

${ }^{3}$ This is not the only reason for subsidising education. Given that many parents are constrained in financing their children's education, there are both equity and efficiency reasons for public support.
} 
example is reading. Once we have learnt this skill, the acquisition of further information and skills is facilitated through book learning.

This view of dynamic feedback can be represented by a function expressing the change in the level of human capital in some representative household as a function of the amount of adult labour time, $\mathrm{L}_{\mathrm{h}}$, that is devoted to education (of self or of children) and the current level of human capital per person, $\mathrm{h}_{\mathrm{t}}$.

$$
\frac{d h_{t}}{d t}=\phi \cdot L_{h} \cdot h_{t}^{\gamma}
$$

The extent of dynamic feedback is captured by the value of the exponential parameter $\gamma$. A value of zero implies that there is no feedback. Aggregate output per person, $\mathrm{y}$, now depends on both physical and human capital per person:

$$
y_{t}=A\left(k_{t}\right)^{\alpha}\left(h_{t}\right)^{\beta}
$$

where we maintain the assumption of diminishing returns by restricting $\alpha, \beta<1$.

Endogenous growth is made feasible by the existence of positive feedback in the second sector of this economy, the education sector. To demonstrate this, take logarithms of equation [4], differentiate with respect to time and substitute equation [3] to derive the growth rate of output per worker:

$$
\frac{d y_{t}}{d t} \frac{1}{y_{t}}=\alpha \frac{d k_{t}}{d t} \frac{1}{k_{t}}+\beta \frac{d h_{t}}{d t} \frac{1}{h_{t}}=\alpha \frac{d k_{t}}{d t} \frac{1}{k_{t}}+\beta \frac{\phi L_{h}}{h_{t}^{1-\gamma}}
$$

Whether or not the accumulation of human capital can drive long-run growth is determined by the final term in this equation. With no positive feedback, i.e. if $\gamma=0$, this term diminishes to zero as the level of human capital, $h_{t}$, increases over time. (This is exactly what happens to the physical capital term, as a given investment rate leads to slower and slower proportional growth in the stock.) But if there is sufficiently high feedback in human capital accumulation, i.e. if $\gamma=1$, the final term in [5] is a positive constant. That is to say, the long-run growth rate is positive. Moreover, it is increasing in the amount of labour time that is devoted to education.

Given sufficient dynamic feedback, public subsidy of education and training can increase long-run growth. In the presence of positive externalities, or other sources of market failure, such policy will also increase economic welfare.

\section{Embodied or disembodied human capital}

Is it reasonable, however, to suppose that the feedback effect is sufficiently strong to make education the engine of long-run growth? Note that even if the feedback parameter is close to unity, say $\gamma=0.9$, the long-run rate of growth in [5] will diminish to zero as the level of human capital increases. Stable long-run growth requires a parameter value of unity. It also requires that there be no limit to the accumulation of human capital. Human capacities to think, organise and remember are, however, usually 
presumed to be finite. Moreover, our skills and abilities die with us and have to be replaced in every successive generation. ${ }^{4}$

In addressing the problem of limits to human capabilities, Paul Romer (1990) emphasises the distinction between the skills and abilities that are embodied in individual humans, and disembodied knowledge. He focuses on the properties of the latter category, the world of ideas and research, supposing that there is sufficient dynamic feedback in the research sector to generate endogenous growth and that the scope for developing new ideas is limitless.

In Romer's model, it is the number of people engaged in research and development that drives long-run growth. His mathematical representation of the generation of new ideas (or blueprints for new products) is similar to that of Lucas' educational sector:

$$
\frac{d A_{t}}{d t}=\phi L_{A} A_{t}
$$

where $A_{t}$ represents the number of productive ideas that have been realised at time $t$ in history and the differential, $\mathrm{dA} / \mathrm{dt}$, is the current output of new ideas from the research sector. $\mathrm{L}_{\mathrm{A}}$ represents the amount of human capital, or the number of researchers, devoted to innovation.

Crucially, Romer assumes that the rate of innovation is directly proportional to the extant stock of knowledge. This is the 'standing on shoulders' hypothesis of knowledge accumulation, so labelled by Charles Jones (1998), in reference to Isaac Newton's disclaimer:

\section{"If I have seen farther than others, it is because I was standing on the shoulders of giants."}

In the accumulation of disembodied ideas, rather than embodied skills, it is indeed plausible to suppose that the level of current output might be directly proportional to the size of the stock. The more ideas and theorems that we have to draw on, the easier it is to generate new ones. Moreover, ideas do not necessarily disappear when their developer dies - they can typically be recorded and transmitted at minimal cost.

Implicit in Romer's formulation of research output is the idea that there is an evenly distributed and infinite universe of potential ideas waiting to be discovered. So a given amount of research effort will produce a predictable number of new ideas. A more realistic approach, allowing the discovery rate to fluctuate, is summarised by Aghion and Howitt (1998) in their discussion of General Purpose Technologies stemming from innovations such as the steam engine, the electric dynamo and the computer.

\section{Non-rivalry of ideas}

As well as hypothesising dynamic feedback in the generation of new ideas, Romer

\footnotetext{
${ }^{4}$ Lucas (1988) asserts that his model of endogenous growth can be sustained across generations if a child's initial endowment of human capital is proportional to the level already attained by the adults - but, unless Lysenko was correct, the genetic transmission of acquired human capital is unlikely.
} 
emphasises that ideas have another significant economic property, non-rivalry. Objects are usually rival, meaning that if you are using something, I cannot use it at the same time. But this is not true of ideas. Once the binomial theorem has been published, your use of it does not in any way interfere with my use of it.

Of course, people can try to stop others from making use of patented ideas. But the excludability of ideas depends on the actions of people supported by institutions of laws and property rights, rather than non-rivalry, which is an inherent features of ideas.

Romer makes use of this distinction by assuming that ideas are fully excludable in their application to the production of goods. For example, a researcher can acquire full patent protection for the design of a new drug; it can only be manufactured if royalties are paid. On the other hand, she has no protection against other researchers who can reverse engineer her ideas and come up with their own different but improved drug design. Indeed, when the original researcher files her patent, she has to describe her idea, thereby providing her rivals with a free input into their subsequent research.

Romer's hypothesis that ideas are non-rival and non-excludable in the research process has important implications for public policy. Researchers may reap the benefits from the direct application of their ideas, but they do not receive monetary reward from others who 'stand on their shoulders'. Left to the market, there will be an under-supply of research effort. Public intervention is required to subsidise research, hence stimulate growth, up to the socially optimum level.

Other aspects of knowledge accumulation are analysed by Aghion and Howitt (1992) and Aghion and Howitt (1998) who emphasise the Schumpeterian notion of 'creative destruction'. Patent rights may bestow monopoly power on the producer of a particular generation of an innovative good; but they cannot prevent the development by a rival of the next generation of goods which are superior in quality and/or price. The creation of the improved version destroys the flow of profits to the previous monopolist. Unbridled competition in such a market can lead to too much research being carried out, where the research is concerned with marginal quality improvements rather than new products and processes. Nevertheless, such research is still capable of driving long-run economic growth.

\section{The Cambridge Counter-Revolution}

The intellectual euphoria of endogenous growth theory was challenged by a group of economists, mostly connected with or based in Cambridge, Massachusetts, who chose to stand behind (or on the shoulders of) Nobel laureate Robert Solow of MIT.

Solow (1994) himself is critical of the knife-edge assumption required to generate stable long-run growth in the models of Romer and Lucas. His point is that these models require the dynamic feedback parameter in the education / research sector to be exactly equal to unity. If we look back to Lucas' model, where the growth rate of the economy is determined by equation [5], we can see that a value of 0.9 for the parameter, $\gamma$, will, eventually, reduce growth to zero: the final term of that equation has $h_{t}{ }^{1-\gamma}$ in the denominator, which drives the term to zero as human capital, $h_{t}$, rises if $\gamma$ is less than one. 
Stable long-run growth requires that the parameter be exactly one.

Romer (1994) has argued that this knife-edge property can be overcome in a more complex model. More damaging to the endogenous growth cause, however, has been the empirical work of another Cambridge (Harvard)-based economist, Greg Mankiw. In a much-cited paper - Mankiw et al. (1992) - he and his co-authors do not tackle the endogenous growth modelers head-on. Rather, they steal the ball of human capital from the endogenous growth scrum and use it to reconstruct the 1956 Solow model.

Their "augmented Solow model" includes human capital as a third factor in the aggregate production function, alongside capital and unskilled labour. They investigate the relationship between steady-state levels of output and the three inputs, using secondary school enrolment rates as a proxy for the rate of investment in human capital. They conclude that the factors are of approximately equal importance - i.e. that the elasticity of output with respect to each factor is approximately one third - and that together they account for eighty percent of the observed variation in 1985 income levels across some 98 nations.

This was a neat sidestep, rather than a direct hit on endogenous growth theory. There was no attempt to directly confront the two models with a discriminating statistical test, but the 1956 model was effectively rehabilitated - even though the econometric evidence is likely to be flawed due to the endogeneity of the explanatory variables. Moreover, this was only half time in the comeback match. In an equally influential second-half, the Mankiw et al. (1992) paper provided a clever re-interpretation of an empirical regularity. Studies of post-war economic growth had typically reported a conditional convergence effect. These studies ran regression models of the form:

$$
\left(\ln y_{i T}-\ln y_{i o}\right)=\alpha_{0}+\beta \ln y_{i o}+\mathbf{g} \mathbf{X}_{\mathbf{i}}+\varepsilon_{i}
$$

where the dependent variable is the growth rate of y, output per capita (or per worker), over a period of $\mathrm{T}$ years. $\mathbf{X}_{\mathrm{i}}$ represents a vector of additional explanatory variables. 'Conditional convergence' is said to exist if the regression parameter, $\beta$, is negative $-\mathrm{a}$ lower starting value for $y$ is associated with a higher subsequent rate of growth, conditional on the $\mathbf{X}$ variables that explain differences in rates of growth.

Previous authors ${ }^{5}$ had interpreted conditional convergence as evidence that technological spillovers from the most advanced economies enabled less advanced economies to imitate and thus enjoy relatively fast productivity growth. The MankiwRomer-Weil re-interpretation of such evidence, echoed by their Harvard colleagues Robert Barro and Jeffrey Sachs, ${ }^{6}$ involves treating the $\mathbf{X}$ variables as determinants of the neo-classical steady state, rather than the long-run growth rate. They then interpret the initial income variable ( $\operatorname{lny}_{0}$ ) as a measure of distance from steady state and the $\beta$ coefficient as a measure of the speed of convergence to steady state.

This re-interpretation of the evidence in favour of the neo-classical model has

\footnotetext{
${ }^{5}$ For example, Abramovitz (1986) and Dowrick and Nguyen (1989).

${ }^{6}$ See Barro and Lee (1994) and Sachs and Warner (1997).
} 
been complemented by the more direct approach of MIT graduate, Charles Jones. ${ }^{7} \mathrm{He}$ highlights the fact that endogenous growth models based on the accumulation of knowledge, such as Romer's model, typically suggest that the rate of growth should be an increasing function of the resources devoted to R\&D. ${ }^{8}$ He cites evidence from the US that contradicts this prediction:

"Since 1950, the fraction of the labour force engaged in formal $R \& D$ has increased by almost a factor of three. Despite these changes, average growth rates ... are no higher today than they were from 1870 to $1929 . . "$

Jones (1998)

Jones also criticises some of the key assumptions underpinning the knowledgebased models of endogenous growth. In particular, he suggests that knowledge creation may become more difficult over time as the easy ideas are discovered first, leaving subsequent researchers with a pool that has been 'fished out'. He also suggests that researchers may often duplicate each other's efforts: 'stepping on toes' rather than 'standing on shoulders'.

These critiques of endogenous growth theory seem to imply that policies aimed at increasing investment in education and/or research will not be successful in raising the rate of economic growth for a sustained length of time. I will argue in the next section of the paper that this is not necessarily the case.

\section{Reconciling conflicting theories of growth}

A crucial difference between the neo-classical and new growth theories concerns the question of whether the long-run rate of growth of the economy is some exogenous constant or whether it can be influenced by public policy. Put another way, the question is whether policies and institutions that influence the rate of accumulation of physical and/or human capital have long-run effects on the level of economic activity or on its rate of growth. For purposes of practical policy-making, however, this distinction may be relatively unimportant - if the 'long-run' never arrives. Looking back to Figure 1, if economies are subject to shocks of sufficient magnitude and frequency, it may be difficult, if not impossible, to tell whether the long-run growth path really looks like path $\mathrm{B}$ or path $\mathrm{C}$. In the 'short-run' - between time $\mathrm{T}_{0}$ when the first major shock occurs and some time $T_{1}$ when another such event occurs - the paths may be virtually indistinguishable.

The evidence of the neo-classical revivalists can be interpreted to support this view. Mankiw et al. (1992), Barro and Sala-i-Martin (1995) and Sachs and Warner (1997) all report growth regression evidence suggesting that the rate of convergence towards steady state is of the order of two percentage points per year, implying that it will

\footnotetext{
${ }^{7}$ See Jones (1995a) and Jones (1995b).

${ }^{8}$ Although Aghion and Howitt (1998) show that their Schumpeterian model of endogenous innovation can be adapted to eliminate the scale effect
} 
take more than thirty years for a country to halve the gap between its current income and the steady state level. ${ }^{9}$ Within a half-life of several decades, we must surely expect that there will be changes in investment rates and changes in the rate of technological progress such that the neo-classical economy is rarely able to get close to steady state.

A useful way to think of this problem is to consider the specification of the Error Correction Model. The ECM is commonly used to decompose macroeconomic timeseries into cyclical and long-run components and to test for long-run cointegrating relationships. A typical regression is of the form:

$$
\left(\ln y_{t}-\ln y_{t-1}\right)=\alpha\left\{\mathbf{X}_{t}-\mathbf{X}_{t-1}\right\}+\lambda\left[\ln y_{t-1}-\beta \mathbf{Z}_{t-1}\right]+\varepsilon_{t}
$$

where y represents real output and the dependent variable is the growth rate of output. The explanatory variables are segregated. The $\mathbf{X}$ variables, which influence short-run movements, are entered in first differences. The $\mathbf{Z}$ factors are entered as lagged variables, along with the lagged value of output, $\mathrm{y}_{\mathrm{t}-1}$. For analysis of the long-run path, the first differences are set to zero, yielding the long run path for output as a function of the $\mathbf{Z}$ variables:

$$
\ln y_{T^{*}}=\beta \mathbf{Z}_{T^{*}}
$$

This very general empirical specification is consistent with both exogenous growth and endogenous growth models. If the $\mathbf{Z}$ vector contains a time trend, $\mathrm{T}$, the regression coefficient on $\mathrm{T}$ is an estimate of the exogenous rate of technological progress - as in the neo-classical model. However, the $\mathbf{Z}$ vector may equally well contain the time trend interacted with another variable, such as the level of human capital. If so, the coefficient on this term captures the impact of human capital on the long-run growth rate of the economy - as predicted by some endogenous growth models.

In the ECM framework, the sign of the regression coefficient $\lambda$ indicates whether output converges to the long-run path. The square brackets in [8] capture last period's deviation from the long-run path. The negative value of $\lambda$ indicates the proportion of last period's 'error' that is 'corrected' in the current period.

A typical time-series study that is trying to identify breaks in trend growth, using thirty to forty annual observations, might find a half-life for the business cycle of two to three years. ${ }^{10}$ In this context, the 'trend' growth is approximated by the average growth rate over one or two decades, averaging out fluctuations over three or four business cycles. But if convergence to the neo-classical steady state growth path has a half-life of

\footnotetext{
${ }^{9}$ Subsequent studies on panel data have estimated higher speeds of convergence: in particular, Islam (1995) and Lee et al. (1997) estimate annual convergence rates up to nine percent and thirty percent respectively. But Dowrick and Rogers (2002) show that these studies confound the effects of neo-classical convergence - due to diminishing returns to investment - with the effects of international technology diffusion. Separating out these effects, they find that the half-life of neo-classical convergence is more than fifteen years.

${ }^{10}$ A pooled time-series cross-section study by Lee et al. (1997), allowing for heterogeneity in countryspecific time trends, has estimated convergence in the Solow-Swan model to have a half-life of 2.5 years. I interpret this as a failure to distinguish the speed of transition to steady state from the fluctuations of the business cycle.
} 
thirty years, this time-scale is clearly insufficient to capture the underlying long-run rate of growth. Rather, we are identifying changes in the slope of the transitional growth path.

This supposition is confirmed by the recent study of Jones (2001). He adopts a modified growth accounting approach to analyse the last fifty years of US growth. He finds that only one fifth of the actual growth rate of labour productivity (averaging 2.0 percent per year) has been attributable to exogenous technical change. The remaining four-fifths of growth (1.6 percent per year) is attributable to continued growth in education and research intensity. In his terms, (p. 23): "Transition dynamics associated with educational attainment and the growth in research intensity account for 80 percent of growth".

Jones' conclusion is couched in the language of the neo-classical approach. Sustained growth above steady state levels can only be transitional and is driven by sustained (but ultimately bounded) growth in the share of GDP going to investment in human capital. An alternative interpretation of the same evidence might claim that increased investment in human capital has raised the long-run endogenous rate of growth.

Evidence that reconciles the two approaches to understanding growth comes from Benhabib and Spiegel (1994) who carry out econometric estimation on various models to explain variation in 20-year growth rates (1965-85) on a cross-section of 78 countries. In their preferred model, technological progress is the sum of two components: an exogenous component, as in the neo-classical model; and a semi-endogenous component, related to the rate of absorption of technology from the technological leading country, captured by an interactive term between the productivity gap and the level of human capital. Their preferred model draws on the analysis of Nelson and Phelps (1966).

They report that the interactive term is statistically significant, supporting the idea that there is an endogenous component to technological progress. At the same time, they estimate an output elasticity close to 0.5 for physical capital, suggesting diminishing returns to investment and a slow rate of convergence towards the steady state capital stock.

Broadly similar results are reported by Dowrick and Rogers (2002). Our study differs from that of Benhabib and Spiegel (1994) in that we carry out the analysis on a panel of growth data. This enables us to test for country-specific effects. We also use an instrumental variable estimator to control for reverse causation between growth and the explanatory variables. Country-specific effects, which we interpret as endogenous components of technical progress, are found to be important. We confirm the finding that the level of human capital facilitates technological catch-up, especially amongst the middle-income and richer countries.

These models combine features of the neo-classical theory with the new growth theory. Changes in the rate of physical investment have, ultimately, only level effects; but within a time frame of one or two decades this is indistinguishable from a growth effect. At the same time, countries have different rates of technological progress with an endogenous component, dependent on the stock of human capital and the allocation of resources to research, and a semi-endogenous component, dependent on the rate of technological change at the frontier and on the country's ability to absorb ideas from 
abroad.

\section{Evidence on Education and Growth}

Some of the earliest studies that investigated the link between education and economic growth were conducted by Mankiw et al. (1992) and Barro (1991). They examined variations in school enrolment rates, using a single cross-section of both the industrialised and the less-developed countries. Both studies concluded that schooling has a significantly positive impact on the rate of growth of real GDP. They interpreted this as evidence of changes to (short-run) transitional growth paths. Barro and Sala-iMartin (1995) also investigated the impact of educational expenditures by governments, finding that they have a strong positive impact. Using instrumental variable techniques to control for simultaneous causation, their regressions suggest that the annual rate of return on public education is of the order of twenty percent. ${ }^{11}$

A series of subsequent studies made use of panel data, examining changes over time in both education and growth. Several of these panel studies - including Benhabib and Spiegel (1994), Islam (1995) and Caselli et al. (1996) - failed to detect any significant relationship between the rate of increase of educational capital and the rate of economic growth. They suggested that the positive findings of the earlier cross-section studies were due to omitted variable bias, failing to control for country-specific effects.

More recently, a third generation of studies has suggested a number of reasons why the negative findings of previous panel studies might have been biased. Pritchett (2001) has argued that poor policies and institutions have hampered growth in many of the least developed economies, directing skilled labour into relatively unproductive activities, hence disrupting the statistical relationship between education and growth in samples that include less-developed economies. Krueger and Lindahl (2001) suggest that the problem of unobserved variation in educational quality is exacerbated in panel data. Taking data quality into account, they show that increases in the stock of schooling do improve short-run economic growth. Hanushek and Kimko (2000) confirm that direct measures of labour-force quality, from international mathematics and science test scores, are strongly related to growth. Temple (2001) finds that growth effects are positive, but non-linear. These non-linear effects may be missed by studies that impose linearity.

Overall, it seems that studies that pool the least and the most developed economies do not find consistent and robust relationships between education and growth.

\footnotetext{
${ }^{11}$ Barro and Sala-i-Martin (1995) report an increasing marginal effect on growth of years of schooling - but this may be due to a lack of variation in the data on primary enrolments. More surprising is their finding that positive growth effects are confined to male education. On the other hand, a study by Caselli et al. (1996) uses a more sophisticated panel estimation technique (General Method of Moments) and reverses the result - it is female secondary education rather than male education that promotes growth. This finding is confirmed by Knowles et al. (2002). These contradictory results probably reflect strong colinearity between female education, male education and other measures of development, such as life expectancy and fertility, which are included in the regressions. Moreover, where many women are involved in domestic rather than market economic activity, the educational enhancement of their contribution to economic welfare may not be picked up directly by standard measures of GDP.
} 
For evaluation of Australian policy, it is probably more useful to examine studies that are restricted to OECD economies.

Mankiw et al. (1992) estimate the determinants of countries' steady-state income levels as a function of investment in both physical and human capital. For their crosssection of OECD countries, they estimate an elasticity of 0.76 between steady-state output and the proportion of the workforce enrolled in secondary school. Translating the elasticity into the marginal impact of an additional year of schooling in OECD countries (where average schooling varies between five and twelve years), this implies that steadystate real GDP increases in a range of six to fifteen percent, with an estimated eight percent increase for a country like Australia with average schooling of ten years.

Bassanini and Scarpetta (2002) analyse panel data, using annual data for 21 OECD countries from 1971 to 1998 . They use a Pooled Mean Group estimator, which allows for cross-country variations in short-run coefficients, but they test for and impose homogeneity on long-run coefficients. Their most reliable estimates suggest that the return to an additional year of schooling is a six percent increase in steady-state output.

Table 1

Predicted increase in the level of output for an additional year of schooling in the adult population of an OECD country

\begin{tabular}{|c|c|}
\hline STUDY & $\begin{array}{l}\text { LEVEL } \\
\text { EFFECT }\end{array}$ \\
\hline $\begin{array}{l}\text { Bassanini and } \\
\text { Scarpetta (2002) }\end{array}$ & $6 \%$ \\
\hline Mankiw et al. (1992) & $6 \%-15 \%$ \\
\hline
\end{tabular}

These macroeconomic estimates refer to that part of the social returns to schooling that is captured in GDP. It appears that these estimates are close in magnitude to microeconomic estimates of private returns to the education of individuals. This implies that the external effects of education are relatively small, at least in the context of the level effects of education.

These conclusions must be modified, however, in the light of a series of empirical studies that have been inspired by the hypothesis of Nelson and Phelps (1966) that human capital may influence the rate of introduction of new technologies. Benhabib and Spiegel (1994), for example, compare models that treat human capital as a direct input into production with models treating human capital as an intermediate input into the acquisition of skills and/or knowledge. The former implies a relationship between output growth and educational growth, whereas the latter implies a relationship between output growth and the average stock of human capital per worker. Their econometric evidence favours the latter model. A more educated work-force can more readily identify, adapt and implement new ideas - whether the ideas are generated domestically or overseas. 
This finding, that education levels affect long-run technological progress, is confirmed by Frantzen (2000) who analyses the growth of total factor productivity (TFP) between 1961 and 1991 in the business sectors of 21 OECD countries. It is also confirmed by Dowrick and Rogers (2002) who investigate the rate of technological convergence between 1970 and 1990 for a wide sample of 51 countries and for a sample of 35 relatively rich countries.

These studies share a common regression specification of the general form:

$$
\text { TFP growth in country } i=\alpha S_{i}+\beta S_{i} f\left(p r_{i}\right)+\ldots
$$

where $\mathrm{S}_{\mathrm{i}}$ is the average years of schooling in the adult population, and $\mathrm{pr}_{\mathrm{i}}$ is the ratio of productivity in the technologically leading country relative to country $i$.

The first regression coefficient, $\alpha$, captures the impact of schooling on domestic innovation. The second regression coefficient, $\beta$, captures the impact of schooling on the absorption of technological spillovers from the technologically leading country.

All three studies find that the level of schooling is a statistically significant determinant of growth. The predicted effect of an additional year of schooling in the adult population on the annual rate of growth of total factor productivity is $\alpha+\beta f\left(p r_{i}\right)$. Considering the case of Australia, where the US productivity ratio is approximately 1.5, we compare the predicted growth effects of schooling in Table 2.

\section{Table 2}

Predicted increase in long-run economic growth in Australia due to an additional year of schooling in the adult population

\begin{tabular}{|l|l|}
\hline \multicolumn{1}{|c|}{ STUDY } & \multicolumn{1}{c|}{ GROWTH EFFECT } \\
\hline Benhabib and Spiegel (1994) & 0.3 percentage points \\
\hline Frantzen (2000) & 0.8 percentage points \\
\hline Dowrick \& Rogers (2002) & $\begin{array}{l}0.2-0.5 \\
\text { percentage points }\end{array}$ \\
\hline
\end{tabular}

* The lower of these estimates is derived using the coefficient reported in Table 2, using the full sample of countries. The higher estimate is from the coefficients in Table 3, using the 35 country sample of relatively rich economies with better data quality.

Even the lowest of these estimates predicts a highly significant boost to annual economic growth, one fifth of a percentage point, for every additional year of schooling.

\section{Australia's educational attainment report}

In the light of these estimates, it is of interest to draw up a report card on 
Australia's record of educational attainment. The data we use are taken from Barro and Lee (2001) who have revised and updated their previous estimates of the average years of schooling in the population aged 25 and over. Figure 2 shows the time path of this measure for Australia and selected OECD countries.

Forty years ago, Australian adults averaged 9.4 years of schooling, a level of attainment that was not only significantly above that of the other countries illustrated, but was surpassed only by New Zealand out of the one hundred countries covered by Barro and Lee. By the year 2000, Australia's average schooling level had climbed to 10.6 years. Attainment rose faster, however, in all of our comparator countries, with the result that Australia has slipped below the USA, Norway, Sweden and Canada and is only fractionally higher than Korea and slightly higher than Japan.

Of course, the average of years of schooling is an imperfect measure of skills and abilities, since educational quality varies across countries and over time, and because it ignores the abilities acquired through experience and workplace training. In the mid1990s twenty countries participated in the OECD's International Adult Literacy Survey. This survey provides a direct comparison of work-related skills, including measures of literacy and numeracy. Figure 3 presents a scatter plot which demonstrates that, on either measure, Australian adults rate close to the OECD average.

The Third International Maths and Science Study, conducted in 1994 and 1995, confirms Australia's average performance. On measures of $7^{\text {th }}$ grade proficiency in Maths and Science, Australian school students ranked fifteenth and twelfth respectively, out of the 37 country scores reported by Barro and Lee (2001).

These international comparisons suggest that Australia's educational report card should be marked: 'Started well, but slackened off. Substantial room for improvement.'

\section{FIGURE 2}

\section{Average Years of Schooling in the Adult Population}

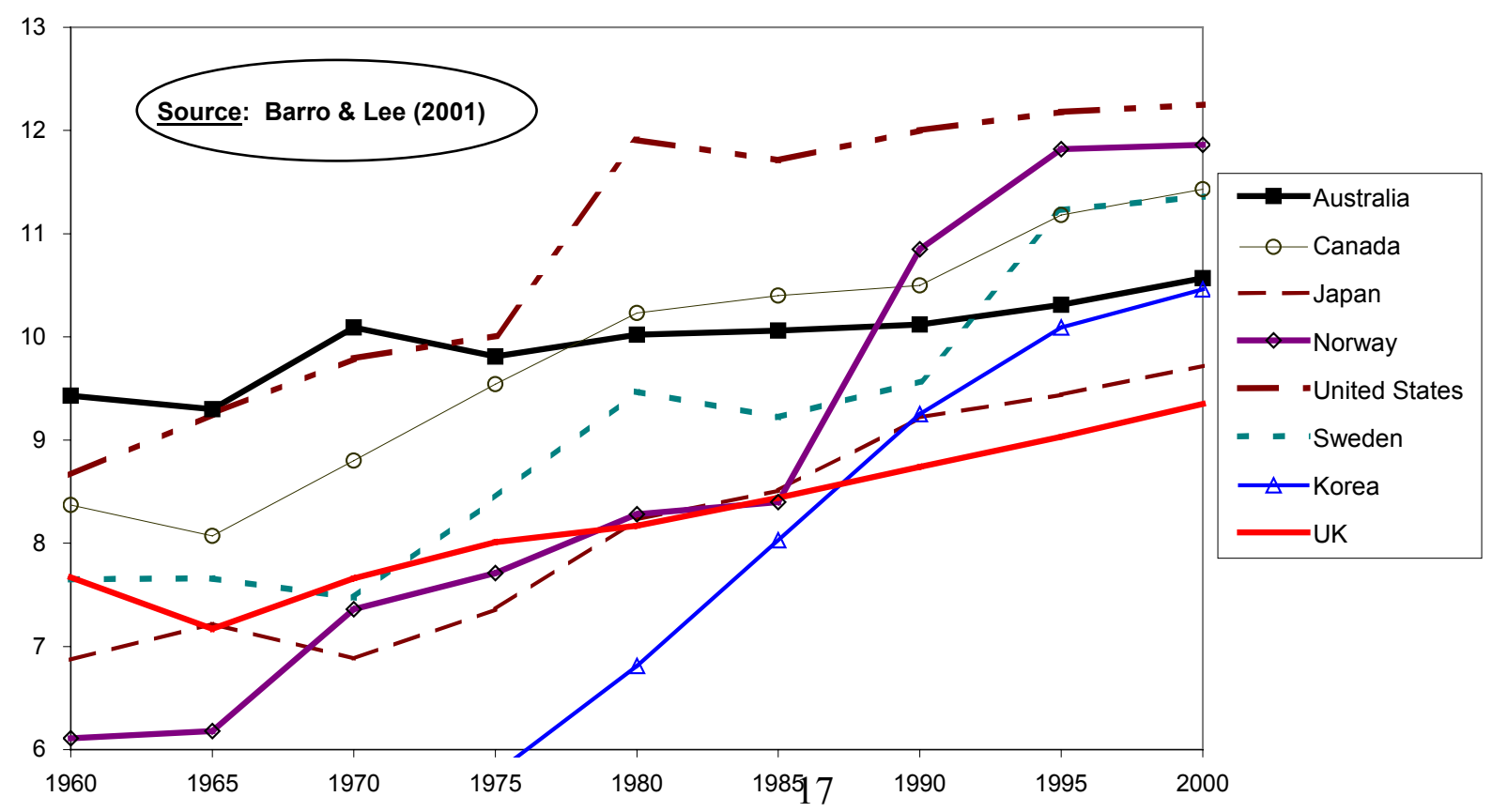




\section{FIGURE 3}

Quantitative and Verbal Skills

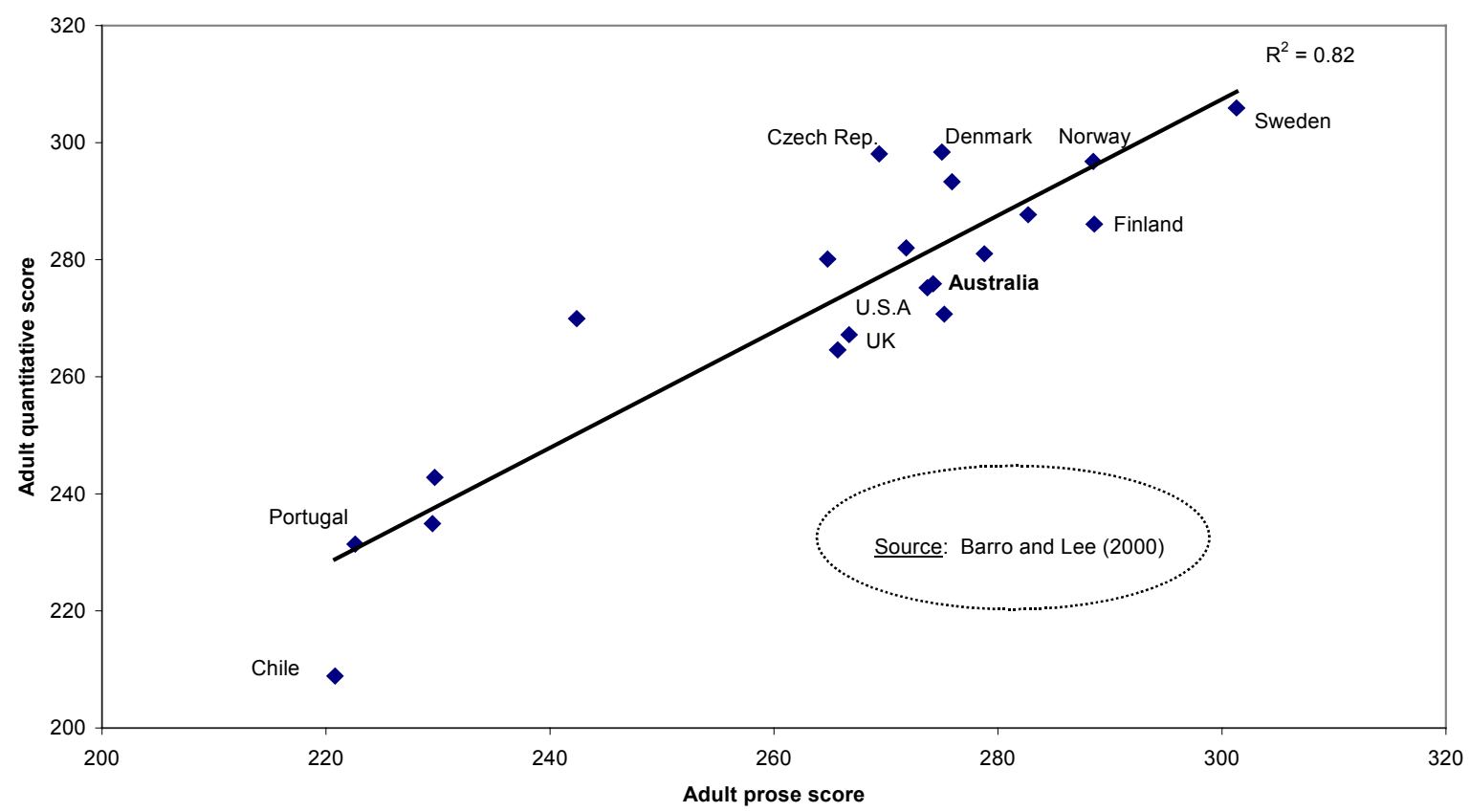

\section{The contribution of R\&D to Economic Growth}

I have already discussed the attributes of knowledge that make it significantly different from the accumulation of items of physical capital. These special attributes are non-rivalry and dynamic feedback. Once a new idea has been generated, it can be used simultaneously and costlessly in many different processes. Furthermore, the idea can serve as an example and inspiration for further research.

These are the attributes of knowledge that give it the potential to drive long-run growth. But the properties of non-rivalry and feedback also suggest that the market may fail to allocate sufficient resources to knowledge generation because individuals have difficulty in establishing and enforcing property rights over their new ideas - some of the benefits of an innovation are likely to accrue to others. When the private return to innovation is less than the social return, governments need to subsidise R\&D.

Paul Romer (1993) has argued that whilst governments should fund fundamental research, it may well be appropriate for self-funding industry associations to fund development and applied research - using government only to enforce the collection of 
agreed contributions. ${ }^{12}$ Weder and Grubel (1993) expand this point in their discussion of the 'Coasean' institutions which operate in various countries to internalise knowledge spillovers and promote technical progress. In particular, they cite the occurrence of three types: (i) industry associations such as the Japanese Keiretsu or Swiss Verbande; (ii) conglomerate corporations, including multi-national enterprises; and (iii) geographic clustering of industries, such as Silicon Valley or the Northern Italian networks. They point particularly to the Swiss and Japanese examples, where voluntary associations, supported by public policy, encourage long-run relationships between vertically related firms and encourage joint ventures and cooperation including joint research and training schemes.

R\&D expenditures typically constitute, for advanced economies, only a few percent of GDP - perhaps one tenth of the expenditure devoted to investment in physical equipment and structures. In a standard growth accounting framework, variations in research effort will, therefore, explain very little of the differences in growth rates between countries. But the point of much of the new growth theory is precisely that if knowledge spillovers are substantial, and if knowledge exhibits dynamic feedback effects, then even small changes in the resources devoted to the production of knowledge may result in substantial changes in economic growth. This point is made by Grossman and Helpman (1991) who calibrate their model to match the US growth experience. They predict that, whilst business investment constitutes around ten percent of GDP, investment in R\&D - the engine of growth - need comprise as little as 1.6 percent to generate economic growth of 2.5 percent per year.

Lichtenberg and Siegel (1991) surveyed some fifteen previous studies into R\&D investment by US firms and industries, reporting real private rates of return averaging $25 \%$. Their own econometric study of two thousand US firms revealed a $30 \%$ rate of return on company funded R\&D, a 'productivity premium' on basic research, and a 7\% return on federally funded company research. These estimates of private rates of return on company-funded R\&D are very high, given that investment in physical capital might be expected to earn a return closer to ten percent. The higher rate of return on research reflects, presumably, a large premium for risk and problems in diversifying or pooling such risk.

Nadiri (1993) confirms that private returns to R\&D are particularly high in his review of the literature: ".. net rates of return on own R\&D of $20 \%$ to $30 \%$ at the firm level and $10 \%$ to $30 \%$ at the industry level are reasonable sets of estimates." He goes on to examine spillovers to other industries and concludes:

"The spillover effects of R\&D are often much larger than the effect of own R\&D at the industry level ... social rates of return often vary from $20 \%$ to over $100 \%$ with an average somewhere close to 50\%.” (Nadiri, pp 34-35)

A subsequent paper by Lichtenberg (1992) is one of the first attempts at studying the cross-country evidence on the impact of R\&D expenditures on both the level and the rate of growth of real GDP. Using a sample of 74 countries, his growth regressions, using the neo-classical framework, reveal that returns to $\mathrm{R} \& \mathrm{D}$ are approximately double

\footnotetext{
${ }^{12}$ Australian agricultural research has long been funded on this basis.
} 
the returns to physical investment - a result that is broadly consistent with estimates from the microeconomic studies of firms and industries.

Coe and Helpman (1995) try to quantify the magnitude of international R\&D spillovers. They seek to explain variations in the annual growth of total factor productivity (TFP) for 21 OECD countries, plus Israel, over the period 1970-90. Their econometric analysis finds that the stock of knowledge in one country, measured by cumulated historical R\&D expenditures, raises productivity in foreign countries with which they trade. It is not clear exactly why the extent of technology transfer should depend on the magnitude of trade with a technologically advanced economy, though their empirical findings appear to be quite robust and have been confirmed by subsequent studies. One plausible explanation stems from the observation by Eaton and Kortum (2001) that the high R\&D economies are also the major world exporters of capital goods. The general trade variable used by Coe \& Helpman may be acting as a proxy for the import of high tech capital goods for which the producers are unable to expropriate all of the rents.

Frantzen (2000) has extended the Coe and Helpman approach and provides us with estimates of rates of return on domestic R\&D as well as estimating the strength of international technological spillovers. He finds that the following regression has strong statistical significance on a sample of 21 OECD countries:

\section{The annual growth rate of TFP in the business sector, 1961-91 \\ $=0.59 \times$ (gross expenditure on own R\&D) / (business sector GDP) \\ $+1.52 \times$ SUM $\{$ (research intensity in country i) * (import share from country i) $\}$}

The first regression coefficient is an estimate of the national (social) rate of return to $R \& D$ - capturing not only the productivity benefits that accrue to the firms which make the investments but also the spillover benefits that accrue to firms in the same or related industries. The second regression coefficient captures the spillover benefit that a country can gain from research carried out by a trading partner. This benefit is proportional to the share of imports from that country in GDP - perhaps reflecting the embodied technological improvements in imported capital equipment.

It is instructive to compare Frantzen's estimates with other estimates of returns to R\&D expenditures. A summary is provided in Table 3. Interestingly, he estimates a 59\% social rate of return on national $R \& D$ expenditures, which is close to the average figure suggested by Nadiri's review of firm and industry-level studies. It is also close to the results of Lichtenberg and van Pottelsberghe de la Potterie (1996) who estimate that the social rate of return on domestic R\&D is $51 \%$ in the large $\mathrm{G} 7$ economies but $63 \%$ in six smaller European countries.

All of these estimates lie substantially above the various estimates of private rates of return, implying that there are very significant spillover effects between the firms and industries within a national economy.

The implication for Australia of the benchmark Frantzen estimate can be 
calculated as follows. Our gross annual R\&D expenditure (public and private combined) of around ten billion dollars amounts to one and a half percent of total GDP, or approximately two percent of business sector value added. An additional billion dollars annual expenditure on $R \& D$, representing one fifth of one percent value added, is predicted to increase the annual growth rate by just over one tenth of a percentage point.

Table 3

\section{Estimated Rates of Return on R\&D Expenditures}

\begin{tabular}{|c|c|c|c|c|}
\hline \multirow[t]{2}{*}{$\overline{\text { Study }}$} & \multirow[t]{2}{*}{ Sample } & \multicolumn{3}{|c|}{ Rates of Return } \\
\hline & & $\begin{array}{l}\text { Private } \\
\text { Returns }\end{array}$ & $\begin{array}{l}\text { Social } \\
\text { Returns }\end{array}$ & $\begin{array}{c}\text { Cross- } \\
\text { country } \\
\text { Spillovers }\end{array}$ \\
\hline \multirow[t]{2}{*}{$\begin{array}{l}\text { Lichtenberg and } \\
\text { Siegel (1991) }\end{array}$} & $\begin{array}{l}\text { i) survey of fifteen previous } \\
\text { studies of US firms and } \\
\text { industries }\end{array}$ & $25 \%$ & & \\
\hline & ii) 2000 US firms & $30 \%$ & & \\
\hline Nadiri (1993) & $\begin{array}{l}\text { survey of fifty US and other } \\
\text { studies at firm and industry } \\
\text { level }\end{array}$ & $\begin{array}{c}20 \% \text { to } \\
30 \%\end{array}$ & $50 \%$ & \\
\hline $\begin{array}{l}\text { Lichtenberg and van } \\
\text { Pottelsberghe de la } \\
\text { Potterie (1996) }\end{array}$ & $\begin{array}{l}\text { GDP growth across OECD } \\
\text { countries }\end{array}$ & & $51-63 \%$ & \\
\hline Frantzen (2000) & $\begin{array}{l}\text { Business sector TFP growth } \\
\text { across OECD countries }\end{array}$ & & $59 \%$ & $45 \% *$ \\
\hline & & & & \\
\hline
\end{tabular}

$*$ if the imports/GDP ratio equals 0.3 .

What would happen if the countries from which Australia imports capital goods were each to increase their research intensity by 0.2 percentage points (the same rise as in the example above for Australia)? If we multiply the regression coefficient on foreign R\&D by Australia's total share of imports in GDP, which is thirty percent, we find that technology spillovers are predicted to increase Australian growth by just over one tenth of a percentage point. In other words, domestic R\&D and spillovers from foreign $R \& D$ are of roughly equal importance for productivity growth.

If these estimates of national rates of return are approximately right, Australia and other OECD countries appear to be suffering from gross under-investment in R\&D. Public and private funds that are currently being devoted to investments with much lower rates of return would be profitably diverted into R\&D. Jones and Williams (2000) reach 
a similar conclusion in their analysis of returns to investment in R\&D in the USA.

\section{Australia's investment in R\&D}

Compared with the leading industrial economies of the OECD, Australia invests less of its resources into R\&D - and a lesser proportion of that investment is carried out within the business sector. In Figure 4 we see that the share of GDP devoted to R\&D in Australia has been growing over the past few decades, from under one percent to around one and a half percent. Our research intensity is, however, still well below that achieved by other major industrial economies such as Japan, the USA and Germany where the $\mathrm{R} \& \mathrm{D}$ ratio has averaged two and a half percent over the past twenty years. On the other hand, Australian R\&D intensity is close to or above that of Canada and New Zealand, countries with comparably large rural sectors. R\&D intensity dipped after peaking at $1.7 \%$ in 1996 . This is attributable in the first instance to a fall in R\&D within the business sector of the Australian economy, which was driven in part by the reduction in the tax concession for R\&D.

Even at its peak, the Australian business sector's contribution to R\&D has been comparatively low. In Figure 5 we see that the proportion of total R\&D that is carried out in the business sector had been rising from 1981 up to 1995 , from $25 \%$ to $51 \%$, but then fell to $45 \%$ by 1998 . In the economies that are illustrated in Figure 6, with the exception of Australia and New Zealand, well over half of national R\&D was carried out by the business sector.

An interesting perspective on Australian performance on a broader measure of 'Investment in Knowledge' comes from OECD (2001) which aggregates expenditures on $\mathrm{R} \& \mathrm{D}$, higher education and computer software. On this measure, Australia ranks fourteenth out of the 24 countries surveyed. In terms of the rate of growth of knowledge investment over the 1990s, Australia ranks tenth. 
FIGURE 4

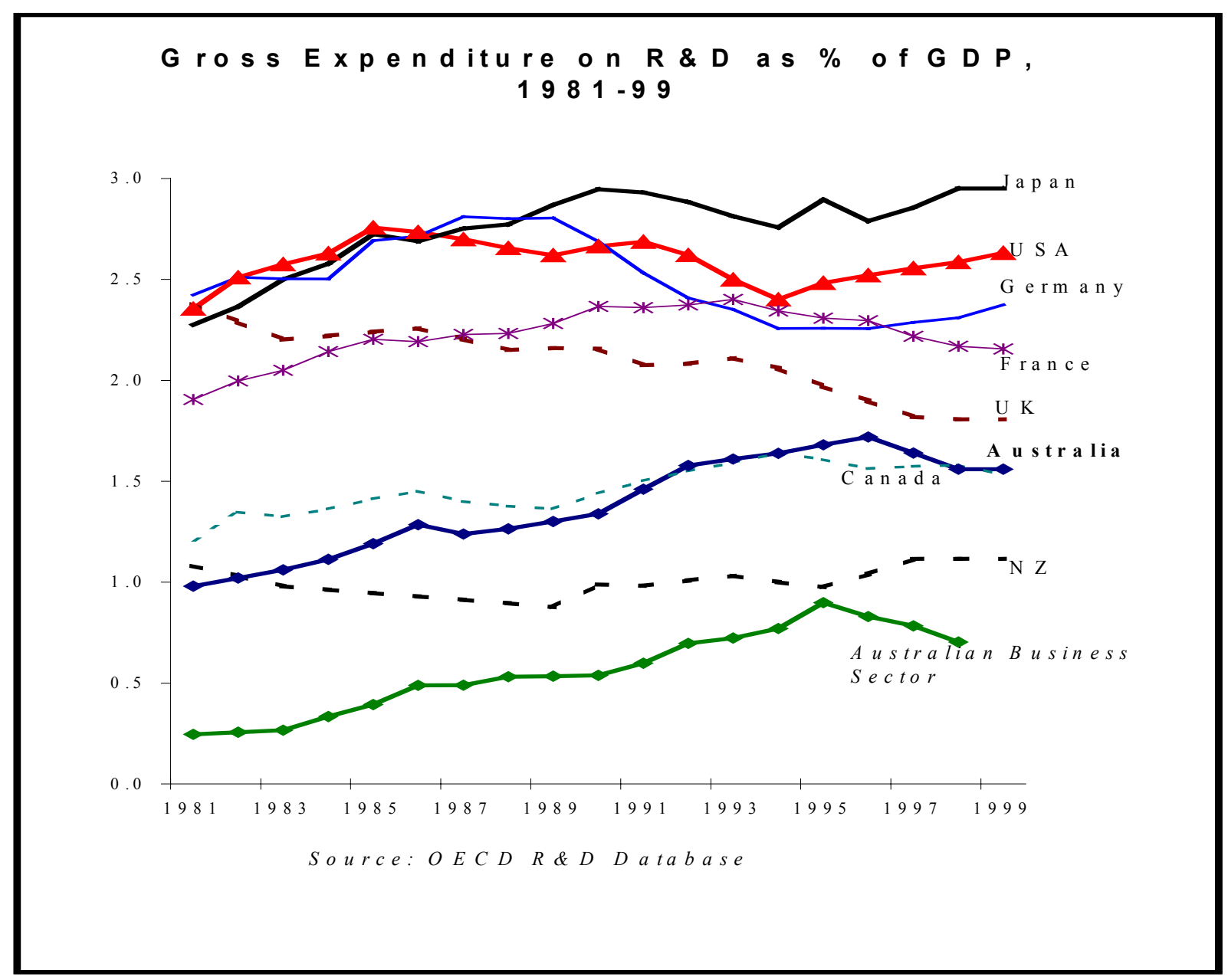


FIGURE 5

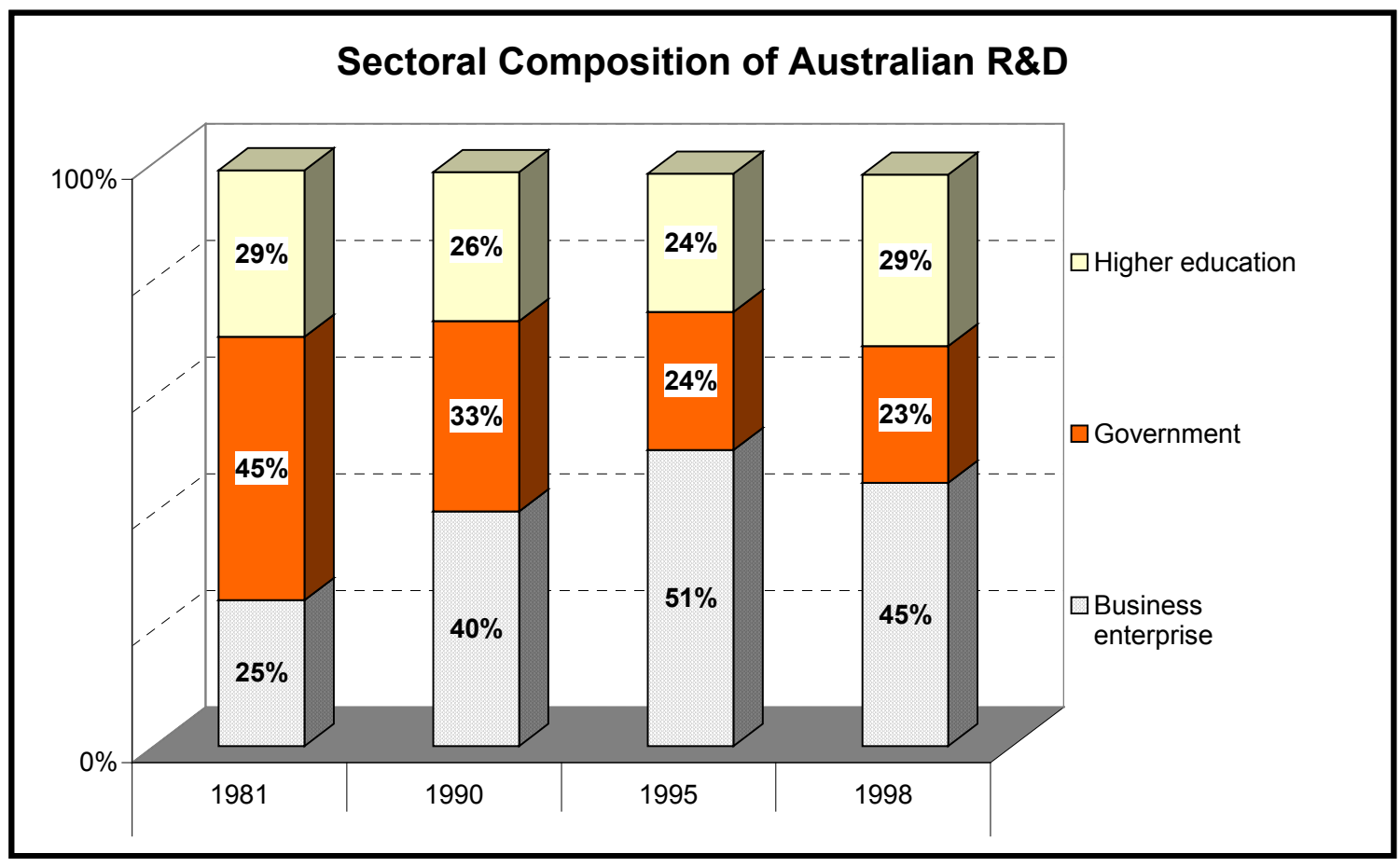

note: the residual category is the share of private non-profit $R \& D$

FIGURE 6

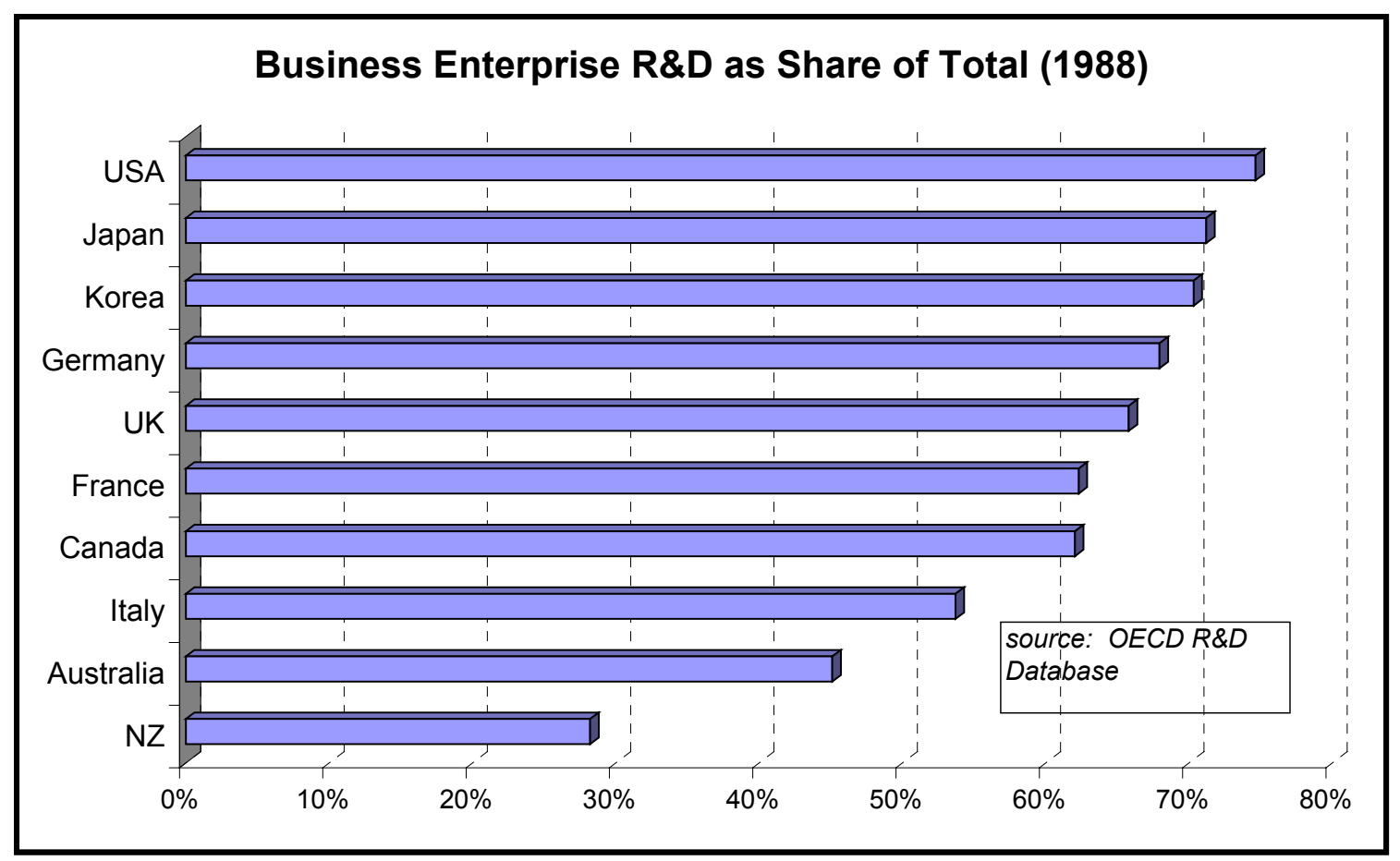




\section{Conclusions}

The neo-classical revival in growth theory has had the paradoxical effect of reinforcing one of the major points of the endogenous growth revolution. The driving force of economic growth is investment in human capital - skills and ideas - rather than investment in machines and buildings. The academic debate will no doubt continue over whether government policies that affect the rate of investment have any influence on the long-run, as well as the short-run, rate of growth of the economy. For practical purposes, however, if the 'short-run' involves a transition period of several decades, this debate may be strictly academic - in the pejorative sense of the word. Policies that affect investment, particularly in embodied or disembodied human capital, can have a sustained impact on economic growth.

A review of empirical studies on sources of economic growth confirms these claims: both education and R\&D are important sources of growth. In the mid 1990s, a number of studies were published claiming that there was no systematic relationship between changes in national educational attainment and changes in economic growth. Subsequent studies have, however, established that this lack of correlation was due to a mix of factors: poor institutional performance in some less developed economies, and a failure to account for international variation in educational quality. Once we account for these factors, the evidence suggests returns to education that are consistent with microeconomic evidence on individual earnings. An increase of one year of schooling in the average educational attainment in the workforce, for example, can be expected to increase the long-run level of output by around eight percent in a typical OECD country.

These are estimates of the level effects of education. A one-off increase in attainment will produce a one-off rise (albeit spread over time) in the level of GDP per capita. There is mounting evidence, however, that there are also substantial dynamic or growth effects, which are linked to a country's ability to implement new technologies. This evidence suggests that Australia would do well to increase its educational levels to match the OECD leaders - the USA and Scandinavia.

One of the concerns of current public debate is that the ageing of the Australian population over the next fifty years will over-tax (literally and metaphorically) the working-age population. From the perspective of growth theory, however, there may not be so much to fear. The ageing of the demographic structure is being driven by the revolution in female education and workforce opportunities. For the generation born in the 1930s, only one third of girls and one half of boys completed high school. For the current generation, over seventy percent of boys and close to eighty percent of girls are completing Year 12. The past fifty years have also witnessed the end of legally enforced discrimination against women in the workforce - in the form of the marriage bar and legalised wage discrimination. These huge improvements in female education and workforce opportunities have been major factors in the fall in fertility, which is the driving force behind the changing age structure of the population.

The very factor that is causing the ageing of the population, the revolution in women's education, gives us reason to expect continued strong growth of the Australian economy. The average educational attainment of the workforce will continue to rise for the next three decades as historical increases in school enrolments work their way 
through the adult population. These effects will be enhanced should educational enrolment continue to rise - particularly if the educational participation and achievement of Australia's young men rises to meet the levels of young women.

The evidence on the benefits of innovation is clear. A wide range of studies finds that private rates of return on $R \& D$ expenditures are very high, and that social rates of return - taking account of intra-national spillovers of knowledge - are even higher.

We can summarise the potential productivity benefits for Australia of increased investment in education and research by using relatively conservative benchmark estimates, based on the large number of studies that have been summarised in this paper. Taking education first, an increase of 0.8 in the average years of schooling of the labour force would take us to 11.4 years, the average of the levels of attainment in North America and Scandinavia. The effect on the Australian economy would be an increase of one third of a percentage point in the annual growth rate - coming both through human capital deepening and more rapid adoption of new technologies. ${ }^{13}$

Turning to investment in $R \& D$, it is probably unrealistic to suppose that Australia will match the research intensity of the world leaders such as the USA or Germany. Adopting a more realistic role model, France, would require that an extra 0.6 percent of GDP be devoted to R\&D - taking research intensity from 1.6 percent to 2.2 percent. Using a conservative estimate of the social rate of return, ${ }^{14}$ the impact on the Australian economy would be an increase of one quarter of a percentage point in the annual rate of productivity growth.

To sum up, positive prospects for continuing strong productivity growth will be enhanced if Australia emulates the higher rates of investment in knowledge - both in education and in research and development - that we observe in the leading OECD economies. An increasingly well-educated (albeit shrinking) workforce, operating in an economy that continues to be open to trade in goods and ideas, will be well placed to identify, introduce and manage the new technologies that will emerge over the next few decades.

\footnotetext{
${ }^{13}$ From Table 1, the conservative estimate of the level effect is $0.8 \times 6 \%=0.048$, which is equivalent to 0.0012 per year over forty years. From Table 2, a conservative estimate of dynamic effect is $0.8 \times 0.003=$ 0.0024 per year. The two effects sum to 0.0036 , or 0.36 percentage points per year.

${ }^{14}$ Assuming the social rate of return is 0.4 , which is substantially below the estimates summarised in Table 3.
} 


\section{References}

Abramovitz, Moses (1986). 'Catching up, forging ahead, and falling behind.' Journal of Economic History 46: 385-406.

Aghion, Philippe and Peter Howitt (1992). 'A model of growth through creative destruction.' Econometrica 60 (March): 323-351.

--- (1998). Endogenous Growth theory. Cambridge, Mass., The MIT Press.

Apps, Patricia and Ray Rees (2001). 'Household production, full consumption and the costs of children.' Labour Economics 8 (6, Dec): 621-648.

Ashenfelter, Orley and Cecilia Rouse (1998). 'Income, Schooling, and Ability: Evidence from a New Sample of Identical Twins.' Quarterly Journal of Economics 113 (1): 253-284.

Ashenfelter, Orley and Alan B Krueger (1994). 'Estimates of the Economic Returns to Schooling from a New Sample of Twins.' American Economic Review 84 (5, December): 1157-1173.

Ashenfelter, Orley and Cecilia Rouse (1997). 'Income, Schooling, and Ability: Evidence From a New Sample of Identical Twins.' National Bureau of Economic Research Working Paper \#5688 (July).

Barro, Robert J. (1991). 'Economic Growth in a Cross Section of Countries.' Quarterly Journal of Economics 106 (2): 407-443.

Barro, Robert J. and Jong-Wha Lee (2001). 'International Data on Educational Attainment: Updates and Implications.' Oxford Economic Papers 53 (3, July): 541-563.

Barro, Robert J. and Jong Wha Lee (1994). 'Sources of Economic Growth.' Carnegie Rochester Conference Series on Public Policy 40 (0): 1-46.

Barro, Robert J. and Xavier Sala-i-Martin (1995). Economic growth. New York; London and Montreal, McGraw-Hill.

Bassanini, Andrea and Stefano Scarpetta (2002). 'Does human capital matter for growth in OECD countries? A pooled mean-group approach.' Economics Letters 74: $399-405$.

Becker, Gary S., Kevin M. Murphy and Robert Tamura (1990). 'Human Capital, Fertility, and Economic Growth.' Journal-of-Political-Economy 98 (5): S12-37.

Benhabib, -Jess and Mark Spiegel (1994). 'The Role of Human Capital in Economic Development: Evidence from Aggregate Cross-Country Data.' Journal-ofMonetary-Economics 34 (2): 143-173.

Borland, Jeff and Xiaokai Yang (1992). 'Specialization and a new approach to economicorganization and growth.' American Economic Review 82 (2, May): 386-391.

Caselli, Francesco, Gerardo Esquivel and Fernando Lefort (1996). 'Reopening the Convergence Debate: a new look at cross-country growth empirics.' Journal of Economic Growth 1 (September): 363-389. 
Coe, David T. and Elhanan Helpman (1995). 'International R\&D spillovers.' European Economic Review 39 (5): 859-887.

Collins, Cherry, Jane Kenway and Julie McLeod (2000). Factors Influencing Educational Performance of Males and Females in School and their Initial Destinations after Leaving School. Canberra, Commonwealth of Australia, Ausinfo.

Dowrick, Steve and Duc Tho Nguyen (1989). 'OECD Comparative Economic Growth 1950-85: Catch-Up and Convergence.' American Economic Review 79 (5): 1010-1030.

Dowrick, Steve and Mark Rogers (2002). 'Classical and Technological Convergence: beyond the Solow-Swan growth model.' Oxford Economic Papers forthcoming.

Eaton, Jonathan and Samuel Kortum (2001). 'Trade in Capital Goods.' NBER Working Paper 8070 (January).

Folbre, Nancy and JA Nelson (2000). 'For love or money - Or both?' Journal of Economic Perspectives 14 (4, Fall): 123-140.

Frantzen, Dirk (2000). 'R\&D, human capital and international technology spillovers: A cross-country analysis.' Scandinavian Journal of Economics 102 (1): 57-75.

Grossman, Gene M. and Elhanan Helpman (1991). 'Trade, Knowledge Spillovers, and Growth.' European Economic Review 35: 517 - 526.

Hanushek, EA and DD Kimko (2000). 'Schooling, labor-force quality, and the growth of nations.' American Economic Review 90 (5, December): 1184-1208.

Islam, Nazrul (1995). 'Growth Empirics: a Panel Data Approach.' The Quarterly Journal of Economics 110 (443) (November): 1127-1170.

Jones, Charles I and John C Williams (2000). 'Too Much of a Good Thing? The Economics of Investment in R\&D.' Journal of Economic Growth 5 (1, March): 65-85.

Jones, Charles I. (1995a). 'R\&D-Based Models of Economic Growth.' Journal-ofPolitical-Economy 103 (4): 759-784.

--- (1995b). 'Time Series Tests of Endogenous Growth Models.' Quarterly Journal of Economics 110 (2 (May)): 495-525.

--- (1998). Introduction to Economic Growth. New York, W.W. Norton.

--- (2001) Sources of US Economic Growth in a World of Ideas. Working Paper. Stanford University: 1-44.

Knowles, Stephen, Paula K. Lorgelly and P. Dorian Owen (2002). 'Are educational gender gaps a brake on economic development? Some cross-country empirical evidence.' Oxford Economic Papers 54: 118-149.

Krueger, Alan B. and Mikael Lindahl (2001). 'Education for growth: why and for whom?' Journal of Economic Literature 39: 1101-1136.

Lee, Kevin, M. Hashem Pesaran and Ron Smith (1997). 'Growth and convergence in a multi-country empirical stochastic Solow model.' Journal of Applied 
Econometrics 12: 357-392.

Lichtenberg, Frank R (1992). 'R\&D Investment and International Productivity Differences.' NBER Working Paper No.4161.

Lichtenberg, Frank R and Donald Siegel (1991). 'The Impact of R\&D Investment on Productivity - New Evidence Using Linked R\&D-LRD Data.' Economic Inquiry 29 (April): 203-228.

Lichtenberg, Frank; and Bruno van Pottelsberghe de la Potterie (1996). 'International R\&D Spillovers: A Re-Examination.' National Bureau of Economic Research Working Paper: 5668 July: 1-16.

Lucas, Robert E., Jr. (1988). 'On the Mechanics of Economic Development.' Journal-ofMonetary-Economics 22 (1): 3-42.

Mankiw, N. Gregory, David Romer and David N. Weil (1992). 'A Contribution to the Empirics of Economic Growth.' Quarterly Journal of Economics 107 (2 (May)): 407-437.

McDonald, Peter and Rebecca Kippen (1999). 'Population Futures for Australia: the policy alternatives.' Australian Parliamentary Library Research Paper 5 (http://www.aph.gov/au/library/pubs/rp/rp99-00.htm).

Miller, Paul W., Charles Mulvey and Nick Martin (1995). 'What Do Twins Studies Reveal about the Economic Returns to Education? A Comparison of Australian and U.S. Findings.' American Economic Review 85 (3, June): 586-599.

Nadiri, M. Ishaq (1993). 'Innovations and technological spillovers.' NBER Working Paper No. 4423.

Nelson, Richard R. and Edmund S. Phelps (1966). 'Investment in Humans, Technological Diffusion, and Economic Growth.' The American Economic Review 56 (1/2, Mar): 69-75.

OECD (2001) STI Scoreboard. Paris.

Pitchford, John (1960). 'Growth and the elasticity of factor substitution.' Economic Record 36 (December): 491-504.

Preston, Alison (1997). 'Where are we now with human capital theory in Australia?' The Economic Record 73 (220, March): 51-78.

Pritchett, Lant (2001). 'Where has all the education gone?' World Bank Economic Review 15 (3): 367-391.

Rebelo, Sergio (1991). 'Long-Run Policy Analysis and Long-Run Growth.' Journal of Political Economy 99 (3): 500-521.

Romer, Paul (1993). 'Idea Gaps and Object Gaps in Economic Development.' Journal of Monetary Economics 32 (3, Dec): 543-573.

Romer, Paul M (1993). 'Implementing a National Technology Strategy with Selforganizing Industry Investment Boards.' Brookings Papers on Economic Activity Microeconomics: 345-390. 
Romer, Paul M. (1986). 'Increasing Returns and Long-run Growth.' Journal-of-PoliticalEconomy 94 (5): 1002-1037.

--- (1990). 'Endogenous Technological Change.' Journal-of-Political-Economy 98 (5): 1990, pages S1971-1102.

--- (1994). 'The Origins of Endogenous Growth.' Journal-of-Economic-Perspectives 8 (1): 3-22.

Sachs, Jeffrey D. and Andrew M. Warner (1997). 'Fundamental Sources of Long-Run Growth.' American Economic Review 87 (2): 184-188.

Shi, HL and XK Yang (1995). 'A new theory of industrialization.' Journal of Comparative Economics 20 (2, Apr): 171-189.

Solow, Robert M. (1994). 'Perspectives on Growth Theory.' Journal of Economic Perspectives 8 (1): 45-54.

Temple, Jonathan RW (2001). 'Generalizations that aren't? Evidence on education and growth.' European Economic Review 45 (4-6, May): 905-918.

Weder, R and HG Grubel (1993). 'The new growth theory and Coasean economics: institutions to capture externalities.' Weltwirtschaftliches Archiv: 488-513.

Yang, Xiaokai and Jeff Borland (1991). 'A Microeconomic Mechanism for Economic Growth.' Journal of Political Economy 99 (31): 460-482. 